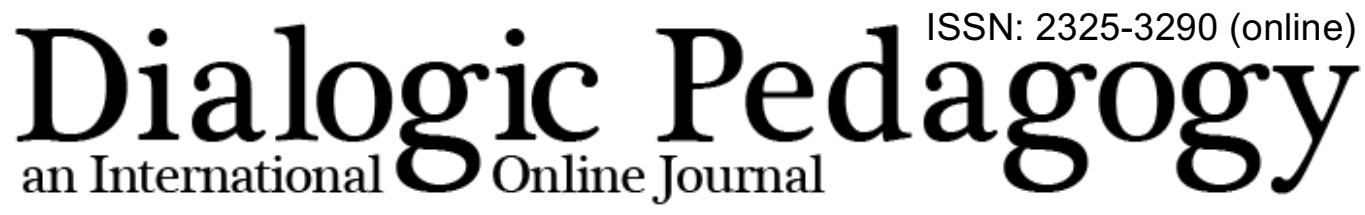

\section{Saint Bakhtin, Porous Theorizing, and Proceeding Nonetheless}

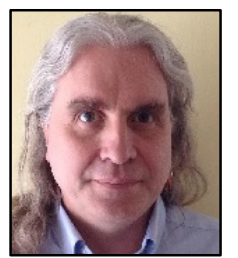

Timothy J. Lensmire

University of Minnesota, USA

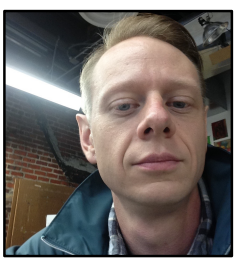

Nathan Snaza

University of Richmond, USA

Timothy J. Lensmire is Professor in the Department of Curriculum and Instruction at the University of Minnesota, where he teaches courses in literacy, race, and critical pedagogy. For his most recent book, White Folks: Race and Identity in Rural America (Routledge), Lensmire talked with white people in the small farming community where he grew up, in order to explore and theorize the complex social production of white racial identities.

Nathan Snaza teaches modern English literature, educational foundations, and contemporary theory at the University of Richmond. He is the co-editor of Posthumanism and Educational Research (Routledge, 2014) and Pedagogical Matters: New Materialisms and Curriculum Studies (Peter Lang, 2016). His articles have appeared in journals such as Journal of Curriculum Theorizing, Journal of Curriculum and Pedagogy, Educational Philosophy and Theory, Educational Researcher, Angelaki, Parallax, Cultural Critique, and Symploke.

$\cos \cos (0)$

\section{Introduction}

Boris Groys seems pretty serious. Not much of a laugher. Not a member of the laughing folk.

Maybe that's why what Groys says about Bakhtin and his theory of carnival feels so stunningly, almost unfathomably, wrong to us. For although we grew up centuries and an ocean away from the carnivals and popular festivals of the Middle Ages and Renaissance that Bakhtin evokes and idealizes, we did grow up-we first became our selves-among the laughing folk of the rural Midwest of the United States. However serious we have since become as scholars and professors, Bakhtin's writing on carnival reminds us of home-of families and communities with their own limits and violences, certainly, but also with a life-sustaining laughter that we've needed in the academy and other spaces dominated by fear and an official truth.

Groys seems pretty serious, so it is at least a little funny that his piece performs a key carnival ritual, the decrowning of the carnival king, which Bakhtin (1984a) thought expressed the "very core of the carnival sense of the world-the pathos of shifts and changes, of death and renewal" (p. 125). In Groys's text, it is not so much a king who is decrowned, but a Saint Bakhtin who gets his halo knocked off. Groys complains that, even though acolytes of Bakhtin sometimes admit that carnival might actually reinforce the official order by providing a safety valve for the folks' wild energies, Saint Bakhtin is allowed to keep 
wearing his "halo of a consistently anti-totalitarian thinker" because it is assumed that he would have been more forthrightly revolutionary if not for the "censorship burden of that time" (p. 2).

Groys is having none of that and his way of bringing Saint Bakhtin down to earth is by associating him and his carnival with Stalin. Groys writes that "obviously" Bakhtin was not a Stalinist, but that "he was not an anti-Stalinist either" (p. 2). If we invoke another of Bakhtin's preoccupations-Dostoevsky's novels-and especially that scene in The Brothers Karamazov in which the people in town and the monastery are waiting anxiously to find out whether the body of a deceased holy man, Father Zosima, will stink as it decomposes, then we can summarize Groys's conclusion thusly: as with the decaying Father Zosima, Bakhtin's carnival corpus stinks. And Saint Bakhtin is no saint.

We agree. Bakhtin is not a saint. And given the positive valuation in Bakhtin's carnival of shit and urine, of the folk running around with underwear on their heads, of childbearing and dying bodies, of the lower bodily stratum in general, then it's fair to say that carnival stinks, too.

In what follows, we try to make sense of how we can read Bakhtin's work on carnival so differently than Groys and why this might matter to us as education scholars. First, we conjecture that we position ourselves in relation to and within Bakhtin's writing on carnival, as readers, quite differently than Groys does. Groys seems to imagine carnival as more totalizing than we do; furthermore, he seems nervous about associating with the folk and about being tested, as a representative of the official culture, by carnival laughter. Then, we try to make sense of how our different way of reading carnival opens onto a larger, more conceptual beef about rigidity and border policing. At a number of key moments, we find Groys wanting to posit neat boxes around things-language and politics in particular-and then judging Bakhtin for not fitting into them. We sketch how we read Bakhtin entirely differently: as a thinker who assumes, ontologically, that borders are never neat and categories are never pure. Finally, we explore an alternative way to understand what Groys thought of as Bakhtin's need to "justify" and "grasp" the Revolution and Stalin's terror in terms of an "a-historic space of pure and universal laughter," as "eternal cosmic tragedy" (p. 4). As educators oriented toward a better future that we'll never live to see, we instead read Bakhtin as understanding how awful and big the world is, how small our efforts, and the dignity and joy of proceeding, nonetheless, in laughing solidarity with others.

\section{Reading Positions}

Six years before Groys's text was originally published, intellectual historian Dominick LaCapra (1983) noted that a "minor cult is presently forming around Bakhtin" (p. 293). However, LaCapra did not think that this fact required the sort of "backlash" that we see performed by Groys, where the importance of Bakhtin's work on carnival is "ignored or denied" (p. 294).

One of LaCapra's key contributions to our understanding of Bakhtin's carnival is his argument that

\footnotetext{
Carnival and carnivalization are for [Bakhtin] crucial dimensions of life that must coexist and interact with other dimensions. That they are the people's 'second life,' as he often puts it, invalidates purely instrumental or functionalist interpretations marked by a spirit of gravity and geared exclusively to questions of political power, social hierarchy, and economic organization. ... the fact that carnival is never a total social environment implies that it is not a self-sufficient entity either in existence or in analysis. ... It tests and contests all aspects of society and culture through
} 
festive laughter: those that are questionable may be readied for change; those that are deemed legitimate may be reinforced. (pp. 305, 306)

Groys often seems, in opposition to LaCapra's argument, to imagine Bakhtin's carnival as a "total social environment." When Groys writes "Simply put, Bakhtin's carnival is horrible-God forbid being part of it" (p. 3), it certainly sounds like someone trapped in something from which there is no escape. Later, Groys claims that Bakhtin's descriptions of carnival were "without a doubt inspired by his experience of the Revolution and Civil War" and that they "reproduce the atmosphere of Stalin's terror with its unbelievable eulogies and vilifications, and also with unexpected crownings and dethronings" (p. 4). This explicit linking of Bakhtin's carnival with Stalin's terror makes it difficult to talk back to Groys without it seeming as if we are making light of the misery and death referenced here.

But whatever its inspirations (and we see no reason not to take Bakhtin at his many words that at least some of this was inspired by Rabelais-channeling-aspects-of-folk-culture), Bakhtin's carnival-"a model ... a philosophical and cultural ideal with important contestatory functions in his own and other modern societies" (LaCapra, 1983, p. 295)—Bakhtin's carnival does NOT seem horrible to us. Indeed, in our initial readings and attempts to make sense of Groys's piece, we were baffled by his "simply put" assertion—an assertion he makes as if it is (or should be) self-evident to any and all readers.

In previous work by one of the authors, four crucial features of Bakhtin's carnival were identified: the participation of all; free and familiar contact among people; a playful, familiar relation to the world; and carnival abuse or profanation (Lensmire, 1994). Groys interprets all of these features negatively.

Where Lensmire interprets the first as signaling inclusion and a rejection of enforced passivity/spectatorship, Groys writes that "nobody is given the democratic right to avoid the total carnival duty" (p. 3). Where Lensmire argues that the second and third features embrace, as Bakhtin (1984b) put it, a "gay and free play [meant] to dispel the atmosphere of gloomy and false seriousness enveloping the world and all its phenomena" (p. 380), Groys sees only the folks' "bodily idiocy" (p. 3).

However, it is probably the fourth feature that best helps us contrast our own reading position to that of Groys. For Groys, Bakhtin's carnival is, in the end, nothing but abuse, a sort of war by everyone against everyone else. But in order to interpret carnival abuse this way, Groys must ignore everything that Bakhtin actually said about it. For Bakhtin (1984a), carnival abuse was antiofficial. The official truth was held in place by fear. Carnival abuse targeted and laughed at the old truth in order to kill it and make space for the new. A "carnival sense of the world" was one with "shifts and changes" and "death and renewal"-carnival, then, was the "festival of all-annihilating and all-renewing time" (p. 125).

We read Bakhtin's carnival among and alongside the folk. Groys does not. His text expresses continual anxiety about being with the folk. Whatever Groys's actual social standing as a person or his everyday perceptions of those below him in social hierarchies, the character of "Groys" in the text who interprets Bakhtin's carnival is an elitist who is afraid of and repulsed by the folk. This "Groys" seems to continually imagine himself as a representative of the official truth who will be laughed at and attacked by the folk (and presumably found wanting). We cannot imagine this "Groys" thinking that there is anything to be learned from or with the folk, cannot imagine him writing, as Bakhtin (1984b) did, that

The culture of folk humor developed through thousands of years [and] has a depth of meaning which is far from naïve. Humor and cynicism may least of all be defined as naïve and do not need our indulgence. Instead they demand our careful and attentive analysis. (p. 152)

Dialogic Pedagogy: An International Online Journal | http://dpj.pitt.edu DOI: 10.5195/dpj.2017.221 | Vol. 5 (2017) 
Simply put, Bakhtin's carnival is wonderful. Or as Lensmire (1994) put it:

In carnival, the people laughed at ideas and practices supposed to be universal and eternal and saw them for what they were-partial and contingent. And for the folk, for everyday people worn down by oppressive conditions, this was a hopeful lesson. (p. 375)

\section{Porous Theorizing}

It seems to us that in his interpretations of carnival, Groys constantly seeks rigid boundaries and insists upon purity within his categories. This quest for rigidity also drives his accounts of Bakhtin's writings on politics and language. We just don't read Bakhtin this way, and for us Bakhtin is a thinker who resists the drawing of clear boundaries and the corollary politics of purity. Partly, this is due to our commitments to feminist and queer theories that eschew the erection and policing of impassable boundaries, even as they focus on the relatively stable or "viscously porous" boundary work that makes bodies and cultures possible (Haraway, 1991; Tuana, 2008). We actually prefer approaches that don't posit a binary opposition between boundaries and formless chaos, and we think approaches that do end up offering readers a kind of ultimatum that tends toward bullying, or even, at times, fascism.

Since Groys's main concern seems to be with politics, we'll start there although most of Bakhtin's writing presumes a particular relation between those politics and language (a relation concretized in what he calls the "verbal-ideological world" in "Discourse in the Novel" [Bakhtin, 1981, p. 270]). Groys's most direct assessment of Bakhtin's politics is, to repeat: "Obviously, Bakhtin was not a Stalinist. But he was not an anti-Stalinist either" (p. 4). Why is Groys so unsatisfied with this?

In terms of the immediate context of the 1930s in Europe, we think Groys is quite correct to draw comparisons here to Georges Bataille and Roger Caillois (we might also include other figures loosely associated with the Collége de Sociologie/Acéphale group, such as Maurice Blanchot). Groys calls these relations "the most direct analogies" possible "in the West" (4). Writing of Bataille, Allen Stoekl (1985) says that "what is crucial to Bataille-and to us-is the troubled nature of his opposition to fascism" (p. 4). In Stoekl's account, and that given by Denis Hollier (1997), what you see is a grappling with "extreme" ways of thinking the social and the political that cannot be understood within contemporary categories of right and left, conservative and progressive. Indeed, what these French thinkers, and Bakhtin, offer us that is crucial is a way of trying to ask about politics, community, and subjectivity that returns them to being questions, not presuppositions within pre-established worldviews. Groys, then, has his own politics (seemingly) sorted out, and holds Bakhtin up to what he takes to be the only proper categories.

This concern with extreme forces and changes in social structures, which took on a particular intensity between the two World Wars, opens onto a more general conceptual problem involving the terms through which we consider politics. For the sake of posing this problem well, we could say that Groys wants to consider Bakhtin's politics, not his conception of the political. We think Bakhtin's writings (we cannot speak to his personal stands on political issues) are best understood as intervening in the political, not in politics. He asks us to consider how languages, ideologies, bodies, and identities interpenetrate, converge, and diverge. He is interested in the "verbal-ideological" becoming of the world as a conceptual, theoretical, and political matter that can only ever be poorly thought within "politics" understood as economic and state practices, or concerns of specific parties or factions.

This is apparent in Groys's subsequent comparison of Bakhtin to the Nietzsche of The Birth of Tragedy. Groys accuses Bakhtin, like Nietzsche, of valorizing the "unconscious and impersonal" 
dissolution that adheres in the Dionysian (p. 5). While it is unmistakably true that Nietzsche does valorize this, and that Bakhtin's notion of carnival has echoes of this, we cannot forget that Nietzsche polemically valorizes the Dionyisan in a context where the Appolonian is considered all important. Against the belief in only rationality, Enlightenment, and distanced judgement, Nietzsche returns us to the importance of emotion, the animality and naturalness of the human, and the joys of ecstatic communion (which is always more-than-human). But Nietzsche (1956) is very clear that what makes Greek civilization so important is that it understood the necessity of both: "They could not maintain [a "third mode" of existence between Apollo and Dionysus] for long themselves, but for that very reason it endures for all time" ( $p$. 125). That is, Nietzsche, and Bakhtin, sought conceptions of the political that were not strictly Apollonian, rational, hierarchized, and driven by forms of knowledge predicated on distance from the world. Whatever forms politics take in a particular moment, Bakhtin and Nietzsche would always remind us that they rely upon and are impossible without a messier world of touch, encounter, and contamination that always already takes place. And we like that messy world. It can be violent and it stinks, sure, but it's also full of joyful laughter and unexpected possibilities.

This same disavowal of the messy world of the political appears in Groys's most direct engagements with Bakhtin's writings on language and literature. Using his (for us, mistaken) reading of carnival as the point of departure, Groys claims that "this means the destruction of isolation, independence, and individuality of the word and the removal of the author's rights to private discourse diffused in the general polyphony of the language, which belongs collectively to 'the people"' (p. 2). Important here is that Groys does indeed note what is Bakhtin's basic ontological claim: that language is dispersed and impersonal, circulating in ways that make it impossible for any individual to claim it as his/her/their own. But Groys seems to mistake this claim about language's mode of being for a political claim: Bakhtin violates a "right" that Groys believes subjects ought to enjoy (which means that Groys ultimately thinks about politics as a kind of necessary taming or disciplining of the messy becoming of the world).

But we have never read Bakhtin as a thinker who demands the elimination of boundaries, although what we love about him is that he is highly attentive to their porosity (to keep using Tuana's word). He in no way rejects individual claims to speech, nor private discourse. In Problems of Dostoevsky's Poetics, Bakhtin (1984a) writes: "The consciousness of a character is given as someone else's consciousness, another consciousness, yet at the same time it is not turned into an object, is not closed, does not become a simple object of the author's consciousness" (p. 6). Here, Bakhtin clearly says characters are and are not closed, are and are not separate from their verbal-ideological surroundings. There is not so much a "destruction of isolation" (as Groys puts it), but a profound pressuring of what "isolation" means: it is not the opposite of community, or something that only appears in the absence of connection, communication, and community. There is, instead, blurring, porosity, and the emergence of relatively stable but ontologically shifting and open boundaries.

If it seems strange here to begin with Bakhtin's writings about literature instead of language in "real" human communities, this is because we want to address Groys's own claims about how these two realms relate. Groys writes that "for Bakhtin, 'other' is always someone inside a novel, and never can it be someone outside of the novel" (p. 4). This is the conclusion of a paragraph that seeks to pitch the "polyphonic novel" as total and totalizing, just as Groys understands carnival to be. In effect, Groys would seem to be claiming that Bakhtin's conception of literature is so totalizing that it swallows reality (something many poorly considered readings of poststructuralist thought also posited; see Coole \& Frost, 2010; Barad, 2007), but this has to forget Bakhtin's conception of "speech genres" (the novel, for him, is one such genre). 
In "The Problem of Speech Genres," Bakhtin (1986) is proposing that stylistics eschew units of analysis that have clearly and easily determined borders (the word, the sentence) in order to focus instead on "the utterance." While the utterance has a very real, material existence, it is conceptually indeterminate. In fact, the only way to know its boundary is to analyze a particular, concrete utterance. This is because its unity is not found in language itself (understood as a set of marks on paper or spoken sounds) but in language's insoluble links to life. Talking about existing systems for categorizing types of language use in Russia at his time (and we might note that this could be applied to so much of what has come to be called "Critical Discourse Analysis" in its more systematic and pseudo-scientific modes), Bakhtin (1986) writes: "All this [confusion and random border drawing] is a direct result of an inadequate understanding of the generic nature of linguistic styles, and the absence of a well-thought-out classification of speech genres in terms of spheres of human activity" (p. 65). That is, for Bakhtin "genres" are direct, concrete, material expressions of "verbal-ideological" worldviews and specific modes of human activity.

This conception of the utterance as something bounded and analyzable only makes sense when positing a real world of touching, of messy relations. Even speaking and listening, the so-called "empirically" separable ends of a linguistic event, blur for Bakhtin (1986): "Any understanding of live speech, a live utterance, is inherently responsive, although the degree of this activity varies extremely. Any understanding is imbued with response and necessarily elicits it in one form or another: the listener becomes the speaker" (p. 68). Activity/passivity and listener/speaker are, for Bakhtin, inescapably necessary distinctions which nevertheless are ontologically and methodologically indistinct. There "are" boundaries, but they are not absolute, not total, not even stable. We have something like consistencies, or intensities, or relatively stable entities, not absolutes. Which is why Groys's attempt to see Bakhtin as "reducing" the world to a novel is so baffling to us: for Bakhtin the novel is in no way separate from the world. It is a "speech genre," one that like, say, ordering a meal in a restaurant or saying "hello" to a passerby, cannot be understood except as an expression of concrete, material human action and movement through the world. And that world, for Bakhtin as for us, is uncertain, shifting, constantly becoming.

\section{Conclusion: Stinky Pedagogies}

If Groys dislikes carnival because it stinks, that's exactly why we love it. We can think about this in two ways. First, as a complaint, the world often stinks: we face political problems-racism, capitalism, heterosexism, ableism, etc.- that mostly feel overwhelming, violent, and immovable. As educators and educational theorists, we seek out ways to bring that immensity down, to see limits as what Paulo Freire (2000) calls "limit-situations": nothing is stable, eternal, immovable. What is, has become, and this implies, of necessity, that it can become otherwise. For us, part of this work is learning, with Bakhtin, to laugh, to take the official down a peg (or two or three), to loosen our grip on thinking that we know the right answers, the right concepts, the "best practices." We don't, and for us this uncertainty - the need to pragmatically and processually pose concepts that we test in action and thought without mistaking them for "real" things-is precisely where pedagogy unfolds.

Purity and rigidity don't do anything for us. We could say again something we wrote a decade ago now: "Students, like teachers, are always directly part of the global economy through their production of communication, affect, and forms of subjectivity. School 'and' society is a false dichotomy; school is society" (Snaza and Lensmire, 2006, p. 14). There is no position outside of the systems we seek to transform, no "purity." Like Bakhtin, we aren't terribly interested in revolutions, but in learning how to better live-with each other, with ourselves-where we are. Our political, and pedagogical, responses to the stinkiness of the world have to stand in the muck. 
And this isn't, for us, a kind of resignation. Growing up around farms, we know intimately how what stinks-manure, compost-is what generates life. The stench of decay reminds us that everything that "is" now, or appears stable, will eventually transform into other things, other forms (and, just as importantly, nothing "is" except as the reconfiguration of other things that have disintegrated). Nothing is permanent. Thus, a second way to think about the stinkiness of carnival is that it helps us to take the long view. All of those things that seem too big to change: they too will dissolve. As educators, we teach, we agitate, we laugh. We go on, together, as best we can. In our stinky pedagogies what we seek is something banal, and something that we think Groys might find too small: experiences, fleeting though they are, of feeling the instability, the impermanence, the constant becoming of the world.

\section{References}

Bakhtin, M. (1981). The dialogic imagination: Four essays. Ed. M. Holquist. Trans C. Emerson \& M. Holquist. Austin: University of Texas Press.

Bakhtin, M. (1984a). Problems of Dostoevsky's poetics. Ed. \& Trans. C. Emerson. Minneapolis: University of Minnesota Press.

Bakhtin, M. (1984b). Rabelais and his world. Trans. H. Iswolsky. Bloomington: Indiana University Press.

Bakhtin, M. (1986). Speech genres \& other essays. Trans. V.W. McGee. Austin: University of Texas Press.

Barad, K. (2007). Meeting the universe halfway. Durham: Duke University Press.

Coole, D. \& Frost, S., Eds. (2010). New materialisms. Durham: Duke University Press.

Freire, P. (2000). Pedagogy of the oppressed. Trans. M. B. Ramos. New York: Continuum.

Haraway, D. (1991). Simians, cyborgs, \& women. New York: Routledge.

Hollier, D. (1997). Absent without leave: French literature under the threat of war. Trans. C. Porter. Cambridge: Harvard University Press.

LaCapra, D. (1983). Rethinking intellectual history: Texts, contexts, language. Ithaca, NY: Cornell University Press.

Lensmire, T. (1994). Writing workshop as carnival: Reflections on an alternative learning environment. Harvard Educational Review, 64(4), 371-391.

Nietzsche, F. (1956). The birth of tragedy \& The genealogy of morals. Trans. F. Golfing. New York: Anchor.

Snaza, N. \& Lensmire, T. (2016). Abandon voice? Pedagogy, the body, and late capitalism. InterActions 2(2): pp. 1-23.

Stoekl, A. (1985). Politics, writing, mutilation: The cases of Bataille, Blanchot, Roussel, Leiris, and Ponge. Minneapolis: University of Minnesota Press.

Tuana, N. (2008). Viscous porosity. In S. Alaimo \& S. Hekman, Eds, Material feminisms (pp. 188-213). Bloomington: Indiana University Press. 


\section{(c)) EY}

New articles in this journal are licensed under a Creative Commons Attribution 4.0 United States License.

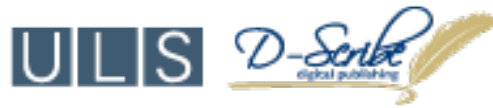

This journal is published by the University Library System, University of Pittsburgh as part of its D-Scribe Digital Publishing Program and is cosponsored by the University of Pittsburgh Press. 